\title{
Borders: Of Boundaries, Transitions and Transgressions - A Response to Gavin Flood
}

\author{
MORNY JOY \\ University of Calgary
}

The basic thesis of this paper by Professor Gavin Flood is that the recent study of religion has largely failed to appreciate the significance of the transformative influence of sacred texts on the existential dimensions of adherents' lives - both private and public. The paper is situated within an approach that Dr. Flood describes as one of 'cultural theology' or hermeneutic phenomenology. It examines what he terms a premodern mindset or orientation, though he allows for a modern disposition on his own part. In keeping with the theme of the conference, I have detected a number of other borders, with their mediatory modes and forms, that are at work in his presentation in addition to those nominated by Professor Flood - namely, those of self, text and world. My own additional nominations of areas where there appear to be certain overlaps and even convergences would be those of Religious Studies and Theology; of interpretation and advocacy; of scholar and adherent or devotee. As a scholar trained in the field of Religionswissenschaft, but also one who has both studied with and been influenced by the work of Paul Ricœur, I have a number of problems with the recommendations made for the study of religion as Dr. Flood has presented them here, because they seem to be in need of certain qualifications. If I continue to employ the metaphor of 'border', it seems to me that his proposals set certain boundaries, rather than fostering a more diversified or exploratory outlook that border-crossing, with its interfaces and moves of transition, or even transgression, can encourage. I would like to address two of Dr. Flood's observations in particular. These are:

1. The centrality of sacred texts to the study of religion.

2. The role of reading in the study of such texts.

Firstly, I have no objection to highlighting the need for the study of the reception of sacred texts, and over the years my own work has profited by 
the study of a number of volumes on this topic, including those edited by Harold Coward with such titles as Sacred Word and Sacred Text (1988) and Experiencing Scripture in World Religions (2000). I do worry, however, about the specific context within which Dr. Flood places the study of the sacred texts. My primary concern is whether the study of sacred texts in a premodern guise can be simply reinserted in an unqualified manner into the study of religion. Unless this approach is carefully contextualized, this would reintroduce, to use a phrase of Paul Ricœur, an analysis that privileges first naiveté. I think there needs to be a primary distinction made between, on the one hand, the religion and texts being studied, together with its believers, and, on the other, the scholar who is undertaking the study. It is fine to acknowledge that a premodern worldview might describe the orientation of the adherents, but the scholar does not necessarily need to defend this position, however appreciative he or she may be of their scripture and its effects. It seems to me there is something of a slippage between these positions in the paper. I am also troubled that this approach is nominated as the preferable way of studying religions. Such a study presumes a number of things, and does not take into account the forceful criticisms that were directed at the study of texts when it was the dominant method of study in the field - even if, at that time, attention was not paid to the existential implications of such texts. I believe that certain of the criticisms that were articulated then remain valid today. I would like to draw attention to them as a cautionary measure before any adoption of Dr. Flood's recommendations is undertaken. These qualifications are:

1. The acceptance of religious scriptures as the primary focus of Religious Studies tends to reinforce what are regarded as the major religious traditions or 'world religions'. This position neglects to observe that other ritual practices, or other modes of behaviour, can co-exist with and be given the same respect as the written word and its recitation.

2. This approach to the study of religions has a predominantly logocentric focus, which both reflects western philosophical categories and employs modes of analysis that can distort depictions of non-western religions.

3. Such a study tends to depict a monolithic view of a specific religion, thus endorsing this tradition in an authoritarian and even prescriptive mode. It thus fails to take into account the many diversifications, such as alternative readings - often deemed heretical variants - that dispute this normative stance. 
In making these observations, I do not want to be mistaken for someone who supports a deconstructionist or relativist position. Nor am I in favour of adopting a constructivist model as the sole way of studying religions. The present impasse between the polarized proponents of theology and of the social-scientific study of religion also continues to be both tedious and unproductive. In my own understanding, there is still much to be learned by different forms of philosophical critique; for example from Habermas's critical theory and its modifications of Adorno and Benjamin, as well as from Ricœur's hermeneutics of suspicion, which acknowledges the challenges raised by such thinkers as Nietzsche, Marx and Freud. Such critical approaches help to discourage reified views and their absolutist pronouncements. It is from such a perspective, then, that I intend to continue by examining the act of reading itself, specifically with regard to religious texts.

The act of reading has always been a privilege of the educated. In this connection, both the study and interpretation of sacred texts in the major religions over the centuries has indeed been predominantly in the hands of a male, usually priestly or clerical, elite. As often as not, it is the interpretations of such scholars that determine what is accepted as sacred or canonical, even if such scriptures are regarded as having been revealed by a divine being. This has a number of consequences. These are evident even, or most especially, in those traditions where, as Professor Flood acknowledges, the majority of practitioners were illiterate. In such contexts, the reading was enacted in stylized ritual performances. These activities were never spontaneous, but highly structured and formalized, guided by ritual experts. A kindred phenomenon was that of mandated or dogmatic interpretations of texts. A particularly striking instance of imposed interpretation is evident in Kathleen C. Boone's study of contemporary Christian fundamentalists, The Bible Tells Them So. Boone observes that ' $[\mathrm{b}]$ ecause the authority of the text is partially constructed by those who interpret the text and because fundamentalism so manifestly effaces the role of interpretation, it has been very successful in winning and sustaining its converts' $(1989,2)$. Along the same lines, Martin Marty and Scott Appleby note that while fundamentalists claim not to interpret, and are often described as literalists, they are in reality tutored by their preachers to be the narrowest and most ideologically directed interpreters (1995). I concede that I may be appealing to the most extreme cases to make my point, but I think it is an obvious illustration of the pitfalls that can occur when uncritical acceptance is endorsed. It may nonetheless be objected that a premodern community is composed of consenting adults, whose faith is such that they accept and do not ques- 
tion authority. But as scholars in today's world, where purely descriptive or phenomenological studies that seek essences no longer suffice, there is a need for a hermeneutics of suspicion. And this brings me back to the work of Paul Ricœur, who was a reader of scripture as well as a philosopher, yet until the end of his life he made a definite distinction between these two modes of study. Ricœur described his own stance as a philosopher as one of agnosticism. From this perspective, he acknowledged that no text is transparent, no reading is ever neutral. This attitude marked Ricœur's own approach as a hermeneutical phenomenologist. And while, in his three volumes of Time and Narrative (1983-8), he may have masterfully described the three different phases of mimesis by which a text is internalized, in his later books he continued to refine what he viewed as the inadequacies of this model. For Ricœur, texts, even while they may inspire us, cannot be taken at their word. Although he allows that certain narratives, including Christian scriptures, can propose a new way of life or being that can be entertained by the imagination, such scenarios need to be submitted to critical ethical evaluation before they are implemented. This is because the prejudices and biases inherent in texts have led to distortions and injustice. He describes such reservations specifically with regard to myth, but I believe his warning is applicable to all forms of narrative, including scripture. 'To the extent that myth is seen as the foundation of a particular community to the absolute exclusion of all others, the possibilities of perversion - chauvinistic nationalism, racism, etc. - are already present' (Ricœur 2004, 120). It needs to be admitted that religious interpretation of its scriptures has not been exempt from adopting such perverse justifications.

At the same time, the discipline of Religious Studies itself has not been without its own chauvinistic impulses. As I have said elsewhere: 'Too often, Religious Studies, including the history of religions, in its early study of other religions, was content to stay within the confines of its own horizon, with the presuppositions or prejudices endemic to the historical constellation of the ideas that have led to its foundation' (Joy 2000, 210). Such a stance can lead to insularity and an assumed sense of superiority when the voice of the other - whether it is that of a dissenter, an indigenous person, or the follower of another religion - has been ignored. Let me be the first to admit that it is an extraordinarily difficult task to maintain a critical attitude towards possible misrepresentation and, at the same time, to allow for the voice of the other to be heard. It is extremely demanding work, which I believe will take all of our energies and critical acumen, as well as a scrupulous honesty. This is because I believe that in our world today we are being faced with unprec- 
edented challenges. To employ a cliché - but one that has ever increasing applicability - we live in dangerous times, with unprecedented challenges. I believe that as scholars of religion in today's world, when certain borders, with their past memories of war and destruction, are being dismantled - as in the expanding European Union - and when, at the same time, others are being rigidly fortified, as when a certain world power (that shall remain nameless) nominates other nations as constituting an 'axis of evil', we need to be aware that there is no longer an innocent or uncompromised position from which to speak. Nor is there any plausible excuse to evoke a mythical past as an ideal or a pristine source by which to judge the present, or even envision a future. This prospect, however, need not be a cause for despair. Instead, it indicates that, in these exceptional circumstances, it is time, as Hannah Arendt would say, to start thinking seriously. At such a time, it is necessary to understand the way in which the social structures of today with their institutions and disciplines, especially those of religion, have been consolidated, and to question the basis of any unqualified claims they may demand. At the same time, practices or proclamations that exclude or vilify an other - be it a people or a religion - that fails to measure up to predetermined standards or ideals need to be examined with greater contextual circumspection. This would also seem a prudent undertaking in a world where, under the aegis of globalization - with its celebratory rhetoric of borderless markets and a resultant worldwide prosperity - many of the actions taken resemble those of colonialism. The similarity can be discerned in the imposition of borders as divisions according to race and class, and a seemingly divinely sanctioned exploitation of various minority groups or regions of the world. This observation may seem to be rather removed from my initial discussion of the problems that can result from uncritical textual interpretations, but religious scriptures, both in the past and in the present, have an uncanny way of being invoked to reinforce rather than reduce dualistic oppositions of an unsavoury nature. It is for this reason that I would caution against any return today to an uncritical study of scriptures in the name of hermeneutic phenomenology under the guise of 'cultural theology'. 
Bibliography

Boone, Kathleen C.

1989 The Bible Tells Them So: The Discourse of Protestant Fundamentalism. Albany NY: State University of New York Press.

\section{Coward, Harold}

1988 Sacred Word and Sacred Text. Maryknoll NY: Orbis Press.

2000 Experiencing Scripture in World Religions. Maryknoll NY: Orbis Press.

Joy, Morny

2000 Beyond a God's-Eye View: Alternative Perspectives in the Study of Religion. - Perspectives on Method and Theory in the Study of Religion, Armin W. Geertz \& Russell T. McCutcheon (eds), 110-140. Leiden: Brill.

Marty, Martin \& Scott Appleby

1995 Fundamentalisms Comprehended. Chicago: University of Chicago Press.

\section{Ricœur, Paul}

1983-88 Time and Narrative. 3 Vols. Chicago: University of Chicago Press.

2004 Myth as the Bearer of Possible Worlds. - On Paul Ricoeur: The Owl of Minerva. Richard Kearney (ed.), 117-126. London: Ashgate. 